\title{
PHILADELPHIA STIRRETH
}

\author{
BY FREDERICK P. GRUENBERG \\ Director, Philadelphia Bureau of Municipal Research
}

In June, Philadelphia friends of good government, by a prodigious
effort, wrested from the legislature important simplification of local
politics, notably the abolition of the two-house council of 145 , and
the substitution of a single-house council of $21 . \quad:: \quad$ :

Absorption in what was transpiring at Versailles did not prevent Philadelphia from applying the self-criticism and constructive impulse of the times to its own local government.

Just as "reconstruction" is used as a shibboleth in every community to cover every needed (or other) program of economic or social action, so has "democracy" become the watchword of political action. In Philadelphia there had long been a feeling of discontent with the antiquated framework of municipal government, and two years ago a number of civic bodies attempted to secure from the legislature the enactment of some twenty measures designed to patch up the defects of the so-called city charter.

The enthusiasm of the legislature's response can readily be measured by the fact that all of the bills died in committee. A quickened sense of political responsibility, however, brought about the organization of a new movement for the legislative session just ended, and it is gratifying to be able to report that a genuine advance has been secured in the direction of more efficient and more democratic city government.

The Philadelphia situation prior to the new charter is by no means easy to comprehend, despite the fact that to the political scientists its organization chart and scheme of government would appear relatively simple-compared, for instance, with Chicago's. The complicating factors in Philadelphia's charter problems are historical and "political," i.e., partisan.

\section{HISTORICAL BACKGROUND}

The historical complications would offer no special difficulties had more Philadelphians been willing to recognize frankly that changed community conditions call for changed machinery - that tradition is of itself not a trustworthy guide to action. It is interesting to note that in this hitherto tradition-bound city there is less adherence to "things as they are" than was formerly the case. Perhaps the war explains the change. However, there still remained a large measure of fondness for the old, and this fondness had been consistently utilized by politicians to continue the status quo. To illustrate-when the present city was welded together out of the old city proper and diverse towns and villages, in 1854, compromises were deemed necessary in order to avert opposition from Germantown and other outlying districts. Accordingly, the citizens of Germantown continue to this day to elect their town clerk, and they and five other sections of the city also elect their poor district officials who levy separate poor taxes for the respective "townships," which condition, by the way, it seems the charter 
revisionists dared not attempt to change.

Under the statute of 1854 , known as the "consolidation act," the county government still continued. The city and county are physically coterminous and their finances as well as many other governmental features were partially unified in the consolidation act.

In 1873 Pennsylvania adopted a new constitution, and, in common with all other state constitutions of that period, a considerable amount of statutory matter was written into its new basic law. Among other things, that new constitution continued the practice of election by the people of a number of county officers, so that a Philadelphia voter at a municipal election is supposed to exercise his discretion in the choice of a long list of officers of widely varying functions and responsibilities.

The only important amendment to the "charter" of 1854 was the Bullitt bill of 1885 which was a great advance in the direction of simplified, responsible government. This bill drew its inspiration from the charter of the city of Brooklyn and its primary purpose was to emphasize the separation of the executive and legislative branches of government, and to concentrate power and responsibility in the mayor. Because of constitutional difficulties, the bill made no changes in the county government, nor did it disturb either the bicameral council or the six poor districts. The council continued to have select and common branches, and as the years went by the aggregate membership grew to the imposing number of 145-the largest municipal legislature in the United States. It is largely because of this obsolete and unrepresentative legislative body that the demand for charter revision became so insistent. Its character and workings will be discussed a little later.
The recent charter revision movement attempted very little to affect the powers and duties of the judiciary. Its emphasis was almost entirely on the legislative and executive branches. The local judges (aggregating 29 in the common pleas, orphans' and municipal courts, and 28 magistrates) are elected by the people. Under the existing arrangement the mayor, the heads of two city and nine "county" departments are also elected. There are a number of boards and officials chosen by the common pleas judges, and the heads of the remaining city departments are chosen by the mayor.

The public schools are not under the city government, but are under a board of public education, appointed by the common pleas judges, which board is empowered by law to levy taxes and to conduct the school system entirely independently of the city government. The school code of 1911 which created this independent status has, on the whole, worked well, but there are many demands for improvements in the school management. These demands found expression in movements independent of that for charter revision, so the details will not be discussed here.

The legislative body, which had been unchanged in general form since 1796, was patterned after the usual parliamentary model of an upper and a lower house. The select council consists of one councilman from each of 48 wards, while the common council seats one from each ward for every 4,000 names on the list of assessed voters for that ward, except that each ward has at least one common councilman.

The old ward lines have undergone but few changes, despite the rapid shifting of population, with the result that one of the older wards has a select councilman and a common councilman to represent a population of five or six 
thousand, while the largest ward has but one selectman and only five common councilmen for a population of not less than 100,000. The fortyeight wards present a wide variety of different populations between these extremes.

Naturally, the above-described permanent gerrymander was resented by every citizen who believes in equitable representation, and as there is no conceivable argument in favor of the existing system, it was doomed to eventual dissolution.

\section{THE POLITICAL COMPLEX}

The situation that for a long time prevented the consideration of the charter proposals strictly on their merits is the strife between the two wings of the Republican organization in Philadelphia. This strife has, to a somewhat lesser extent, spread to the state organization.

The local government is under the control of the branch of the organization led by State Senator Edwin H. Vare, opposed to which is the faction led by Pennsylvania's senior United States senator, Boies Penrose. The governor and the majority of the state legislature are generally believed to be friendlier to the Penrose faction.

In Philadelphia the latter group, being the "outs," have allied themselves with various groups of "independents" and "reformers" in attacking the Vare faction, the "ins." When the recent demand for charter revision arose, most of the Penrose adherents were found associated with their former enemies, the reformers. The Vare faction promptly proceeded to brand all the charter proposals as partisan in character and the Varecontrolled city councils passed a lengthy resolution lauding Philadelphia's perfect frame of government and pleading with the legislature and the governor not to disturb the beautiful symmetry of the venerable system.

In the meantime the self-constituted citizens' charter committee had begun to crystallize the existing sentiment in the city in favor of a better charter, and all the newspapers aided the cause. When this sentiment became discernible, the Vare faction skilfully altered their tactics and declared that there was undoubted need for certain changes in the framework of the city's government, but that the charter committee's bills were unsatisfactory. Thereupon they introduced a measure described as one that would "take the police out of politics" and another ostensibly for the purpose of reforming the city's financing. A careful perusal of each of these measures disclosed nothing but perfect red herrings. As a means of confusing the legislature and as a means of complicating the problem of charter revision these measures were well conceived, but no impartial critic could find in them any contribution to the strengthening or bettering of the municipal machinery.

While the proposals of the charter committee were declared, by their Vare critics, to be "tarred with the Penrose stick," the measures were really by no means partisan in character and were drafted by students and specialists, after many weeks of study of the needs, and of the constitutional and other technical aspects. In only one important respect, in the opinion of the writer, did the charter committee succumb to the temptation of nursing the Penrose support. That one matter was in connection with the board of revision of taxes--the tax-assessing body of the city. That unit of the local government had been much criticised by various elements in the community, and many reasons for its reorganization 
are repeatedly urged, yet certain of the leaders in the charter committee carefully avoided this issue, admittedly lest they offend their political allies.

The merits or faults of the charter bill, it must be conceded, did not determine its passage nearly so much as did the political situation. The Penrosites and the handful of Democrats supported the independents and so got the bill through, but not until Governor Sproul and his attorneygeneral had dictated a number of important amendments-some as sops to the Vare followers, some of no significance at all, and some that they no doubt honestly believed to be improvements. The amended bill passed late in June, just before the adjournment, and it received the governor's signature on June 25. It had been introduced by Senator George Woodward (described as an independent, elected with Penrose support) on March 3, nearly four months of suspense, legislative inaction, lobbying, and machination thus intervening.

\section{THE CHANGES PROPOSED, AND THOSE SECURED}

The charter bill was a compromise measure, as are most legislative proposals of its character. It provided, however, an inclusive frame of government to the extent that the state constitution and our limited political education permit at this time. Because of limitations of space we shall not attempt to go into great detail regarding each proposal nor even as to each final amendment of the city's former charter, but shall confine our discussion to the more important of each of these groups.

The major change proposed was in the municipal legislative body. In lieu of the two large chambers, a single body, based on the existing eight state senatorial districts, was created with provision for a councilman for every 20,000 assessed voters. Proposals to secure some representation at large, as well as a splendid effort to introduce some rational system of proportional representation, were defeated in the charter committee. After violent debate and various attempted amendments in the legislature the council in the new charter is as originally proposed by the charter committee, giving us a council of 21 to begin with.

The powers of the mayor are somewhat modified in the new act. There are some structural improvements in the departments under his jurisdiction such as the separation of health and charities (now under one department) and the creation of a new department of welfare to cover the charity, corrections and recreational functions, but more especially to work along modern social lines. The efforts to shorten the ballot were restricted by constitutional provisions, but a step in this direction was taken in the proposals that the city's chief law officer, now elective, be appointed by the mayor, and that the position of receiver of taxes, a purely ornamental elective office, be abolished. As the act finally passed, the charter committee and the reactionaries divided honors-the city solicitor becomes appointive, but the status of the receiver of taxes remains unchanged.

The civil service and corrupt-practises laws, which were passed in the famous "penitential" legislative session of 1906, are somewhat strengthened and improved. In lieu of a civil service commission of three appointed by the mayor, a single commissioner, elected by a two-thirds vote of the council, was proposed by the charter committee. The committee was also desirous of extending the trial-board privilege, now accorded only to police- 
men and firemen, to all civil servants, but in the course of the legislative amending the size of the commission was restored to three chosen by the council, however, instead of by the mayor. The proposal to extend the trial-board privilege to others than policemen and firemen was eliminated. Pernicious political activity of policemen and firemen is effectively checked and the too-wide choice of four eligibles for a single vacancy is reduced to two. In a supplementary bill an attempt was made by the revisionists to extend the merit system to "county" as well as to all "city" departments, but this bill never got out of the senate committee.

The charter bill set up fundamental reforms in the fiscal procedure of the city by requiring a mayoral budget without, however, restricting the freedom of the council in its action on it. This article of the charter required financing on a revenue and expense accounting basis instead of on a basis merely of cash receipts and cash disbursements as the existing law provided. The initiation by the mayor, and the untrammeled freedom of ultimate action by the council, survived the legislature, but the accounting reforms were ripped out because the governor's attorney-general insisted that they were "too technical."

The powers of the city controller are enlarged to give him jurisdiction over all the city's bookkeeping, thus making it possible to have a centralized accounting system in place of the numerous systems in the several departments and bureaus now existing in addition to that in the controller's office. A short article simplifying and improving the legal mechanism controlling municipal indebtedness follows the article on budget, and through some miracle this part of the charter bill came through unscathed.
Philadelphia is one of the last if not the sole remaining large city in the civilized world that has its street cleaning and waste removal done by private contract. In recent years there has been growing discontent with the inefficiency of these services and studies of the methods employed elsewhere revealed the fact that these functions are usually performed by the municipalities themselves. Accordingly, the new charter requires the city to do its own street cleaning and waste removal after December 31 , 1920. In deference to the home rule principle, and with the thought of providing for some unforseeable situation, it is stipulated that work of this character may be done by contract if the council, by a majority vote, with the approval of the mayor, so decides. The original proposal of the charter committee was to make the exception only if three quarters of the council and the mayor consented to do this kind of work by contract, and around this point was waged the most hotlycontested fight in the charter campaign, the governor finally ordering "majority" substituted for "three quarters." The charter act also makes it possible for the city to enter into contracts for periods longer than one year, a right not allowed under the present statutes. By this means it is hoped to make it possible to secure genuine competition in bidding on municipal contracts, a result not obtainable under the oneyear limit. The reason for the latter fact is that potential competitive bidders find it impossible to provide the necessary plant and other facilities for use in contracts that may last but one year.

Many of the provisions of the charter just made law by the governor's signature are either merely mentioned or entirely omitted from this very condensed sketch. An effort has been 
made, however, to touch upon the essential features of the program and the final act and to make clear the main changes and the objects sought to be attained. By this new charter- but no less by the civic education that its advocates and opponents furnished -old Philadelphia has taken a giant stride forward into the ranks of progressive American municipalities.

\title{
THE PRESENT STATUS OF THE EXECUTIVE BUDGET IN THE STATE GOVERNMENTS
}

\author{
BY A. E. BUCK \\ New York Bureau of Municipal Research
}

\begin{abstract}
Many persons will be agreeably surprised to learn that the legislation stage of the budget movement in state governments is near completion, so widely has the principle now been written into law. There remains the necessity of making public officers conform to its spirit. $\quad$ :: $\quad$ ::
\end{abstract}

ONLY within the last ten years has any recognition been given in this country to the importance of sound principles of budget making as a means of avoiding waste in public expenditures and of securing better service in public administration. In fact, the first thorough study of budgetary procedure to be made in this country was that produced in connection with an investigation of the appropriation methods of the national government by President Taft's commission on economy and efficiency, which was organized in 1911. As a result of the work of this commission Mr. Taft came out strongly for an executive budget and embodied his proposals in a message to congress on June 27, 1912. Although congress did not act favorably upon the President's recommendations, their effect was not lost. Almost immediately the discussion occasioned by them spread to the states, with the result that the term "budget system" found a prominent place in party platforms and became a vital issue in state politics. Several of the states whose finances were in a depleted condition were already feeling keenly the need of a uniform system of control over their revenues and expenditures-a system which would correlate the two and establish definite administrative responsibility. Consequently they at once seized upon the idea of a budget system and embodied a form of budgetary procedure in their law. Because of only a meagre understanding of the principles of a correct budget system and, in some instances, because of political expediency the type of budget adopted did not always fix definite responsibility and the budgetary procedure provided was usually very incomplete.

\section{BUDGET MOVEMENT IN THE STATES}

The movement for budgetary reform in the states may be said to have actually begun in 1913, although two years prior to this time Wisconsin and California enacted laws containing some provisions for the establishment of budget methods. During 1913 six states enacted budget legislation, the laws of three of which, namely, Arkansas, Ohio and Oregon, have not since been revised. Each year since 1913 budget legislation has been enacted in one or more states. Beginning with 1916 an increased number of states 